\title{
Mobilidade identitária em Nihonjin, de Oscar Nakasato
}

\begin{abstract}
Alice Áurea Penteado Martha ${ }^{1}$
\section{Introdução}

Romance de estreia de Oscar Nahasato, Nihonjin, recebeu, em 2011, o Prêmio Benvirá de Literatura e dividiu, no mesmo ano, o Prêmio Bunkyô de Literatura com Retratos japoneses no Brasil, organizado por Marília Kubota e com Contos do Sol Nascente, de André Kondo. Em 2003, o escritor havia vencido, além de outros, o Concurso Literário da Secretaria de Estado da Cultura do Paraná, Prêmio Especial Paraná, com o conto "Menino na árvore", publicado em antologia pelo governo do Estado do Paraná. Em 2012, concorrendo com Ana Maria Machado, autora já laureada anteriormente com o Prêmio Jabuti, e outros nomes consagrados da literatura brasileira, vence o concurso de melhor romance, em meio a uma polêmica nacional, que resultou em inúmeros artigos, entrevistas e comentários em todos os veículos da mídia brasileira. Entre tantas publicações, destacamos um excerto divulgado na Folha de S. Paulo, em 19 de outubro de 2012, que discute a participação do jurado que atribuiu notas muito baixas aos outros concorrentes:
\end{abstract}

Ninguém tem dúvida de que Ana Maria Machado é uma excelente escritora. Ou tem? Eu não tenho. Não fosse o jurado $C$, ela acrescentaria à sua prateleira mais um merecido Jabuti. Querendo ou não, o jurado C pôs no topo um estreante, alguém que não teve destaque ao ser publicado e que no entanto foi merecedor de figurar entre os finalistas, tendo concorrido com mais de cem títulos. Em última instância, é melhor que estejamos sendo apresentados a Oscar Nakasato do que que venham nos repetir que Ana Maria Machado é uma excelente escritora (Cozer, 2012, s.p.).

Em várias entrevistas, Oscar Nakasato, defendendo a mudança no regulamento do prêmio da Câmara Brasileira do Livro ( $\mathrm{CBL}$ ), promotora do evento, considera, sem arroubos, a situação constrangedora em que foi lançado com a premiação:

Esse prêmio devia me proporcionar apenas alegria, mas me causou um desconforto muito grande. Em muitos momentos, um desconforto maior que a alegria. [...] Essa especulação de que houve manipulação para eu ganhar tem me incomodado além da conta [...], as notas dadas a Ana [Ana Maria Machado]

1 Doutora em letras e professora da Universidade Estadual de Maringá (UEM), Maringá, Paraná, Brasil. E-mail: apmartha@uol.com.br 
foram muito estranhas. Se fosse comigo, também acharia estranho. Se tivesse ficado apenas entre os dez finalistas, sem ter ganhado, talvez tivesse sido melhor (NAKasato apud Almeida 2012, s.p.).

Polêmicas à parte, Nihonjin é um romance escrito com delicadeza e cuidado, uma história bem contada, dessas que o leitor não quer fechar o livro sem conhecer seu final. A simplicidade e a contenção das emoções de um autor que poderia impregnar sua narrativa pela proximidade com as questões do mundo narrado, uma vez que, como nikkei (neto de japoneses), sua história pessoal possui íntimas conexões com a de Hideo, o imigrante que dá origem à saga contada. Esse é um dos aspectos levantados pelo escritor e crítico literário José Castello (2012, s.p.):

Um romance simples que, fiel a um passado anterior à revolução modernista, no qual se ambienta, guarda a aparência de um álbum de recordações íntimas. Álbum composto não de fotografias, mas de relatos que têm como único objetivo registrar impressões e capturar nacos da memória. Mesmo nos momentos mais dramáticos, como a morte de Kimie, primeira e frágil mulher de Hideo, que faleceu com a esperança de ver os cafezais paulistas cobertos de neve, um prudente Nakasato não se permite o extravasar das emoções. A contensão que caracteriza sua escrita se expressa neste breve trecho: "A morte chegou lentamente. Há quanto tempo morria? Tranquila, congelada pela neve, congelada pelo sol”.

Essas premissas encaminham o objetivo deste texto, que é, em última instância, analisar o movimento de "des(re)territorialização", entendido como mobilidade na literatura, na obra Nihonjin, do escritor paranaense de Oscar Nakasato (2011), a partir de conceitos como "desterritorialização" e "reterritorialização", termos atribuídos a Gilles Deleuze e Félix Guattari (1992), e também utilizados por Néstor García Canclini. Com a leitura do romance, procuramos observar, no plano formal, as fronteiras por onde se movem o narrador e suas criaturas ficcionais, ressaltando modos de construção do mundo narrado, especialmente a ambientação; e no plano temático, consideramos a inserção das personagens em novos territórios, engendrados pelo movimento da ação narrativa.

\section{Desterritorialização e reterritorialização}

Gilles Deleuze, embora já trabalhasse com esses termos na elaboração do conceito de "território", reconhece sua origem no pensamento de Félix Guattari:

eu, por determinadas razões, tive que refletir sobre essa noção de território. E disse a mim mesmo: o território só tem valor em relação ao movimento pelo qual se sai dele. A partir daí, com Félix [Guattari], construiu-se um conceito de que gosto muito, que é o de desterritorialização. Sobre isso nos 
dizem: é uma palavra dura, e o quer quer dizer, qual a necessidade disso? (Deleuze, 1997, vídeo).

Em Mille plateaux: capitalisme et schizophrénie (1980, p. 364), Deleuze e Guattari apresentam uma primeira definição do termo: "D é o movimento pelo qual 'se' abandona o território", e, observando que tudo - animais, plantas e homens - o que é desviado de seu lugar de origem é desterritorializado, consideram, por exemplo, um cajado como "um ramo desterritorializado" (Deleuze; Guattari, 1991, p. 66). Outro termo importante para este estudo é o de reterritorialização, também buscado nos estudos dos filósofos Deleuze e Guattari (1980). Para eles, não devemos confundir o processo de reterritorialização com mero retorno ao território original, de onde fomos desterritorializados, pois se trata de uma operação original: "a reterritorialização não exprime um retorno ao território, mas relações diferenciais interiores à desterritorialização" (Deleuze; Guattari, 1980, p. 635). Para eles, os fenômenos ocorrem de forma conectada, não há desterritorialização sem a consequente reterritorialização:

A função de desterritorialização: D é o movimento pelo qual "se" abandona o território. É a operação da linha de fuga. Porém, casos muito diferentes se apresentam. A D pode ser recoberta por uma reterritorialização que a compensa, com o que a linha de fuga permanece bloqueada; nesse sentido, podemos dizer que a D é negativa. Qualquer coisa pode fazer as vezes da reterritorialização, isto é, "valer pelo" território perdido; com efeito, a reterritorialização pode ser feita sobre um ser, sobre um objeto, sobre um livro, sobre um aparelho, sobre um sistema (Deleuze; Guattari, 1997, p. 224).

Ao estabelecerem comparações entre o nômade e o migrante, os filósofos apontam traços fundamentais das relações entre os conceitos "desterritorialização /reterritorialização":

se o nômade é o Desterritorializado por excelência, é justamente pelo fato de que a reterritorialização não se faz após, como no caso do migrante, nem em outra coisa, como no caso do sedentário [...]. Para o nômade, ao contrário, é a desterritorialização que constitui a sua relação com a terra, de maneira tal que ele se reterritorializa sobre/com a própria desterritorialização. É a terra mesma que se desterritorializa, de tal forma que o nômade encontra nela um território. A terra deixa de ser terra e tende a tornar-se um simples solo ou suporte (Deleuze; Guattari, 1980, p. 473).

Para Octavio Ianni, a globalização, responsável pela desterritorialização na pós-modernidade, acarreta inúmeras implicações, tanto no que se refere aos aspectos sociais, como aos campos político, econômico e cultural: 
À primeira vista, a desterritorialização lança a ideia de sociedade global no cerne da pós-modernidade. Aí muita coisa muda de figura, desloca-se, flutua, adquire outro significado, dissolve-se. Ao lançar-se além dos territórios, fronteiras, sociedades nacionais, línguas, dialetos, bandeiras, moedas, hinos, aparatos estatais, regimes políticos, tradições, heróis, santos, monumentos, ruínas, a sociedade global desterritorializa tudo o que encontra pela frente. E o que se mantém territorializado já não é mais a mesma coisa, muda de aspecto, adquire outro significado, desfigura-se. Rompem-se os quadros geográficos e históricos prevalecentes de espaço e tempo. Emergem outras conotações para o que é singular, particular, universal, em outras mediações (IANNI, 1995, p. 103-104).

Deleuze e Guattari comparam o nomadismo a uma máquina de destruição [guerra] contra a ordem, que procura fixar e enraizar os seres em uma ordem transcendental. O nomadismo é uma forma de agenciamento que transforma o pensamento pela renegociação permanente, a experimentação constantemente adaptada a um contexto móvel; o pensamento, por seu turno, deve ser nômade, móvel, fluido, resistente ao fixo e à ordem. A ideia de conjunto, de agenciamento, é chave para compreensão da noção de território, segundo os filósofos:

Todo agenciamento é, em primeiro lugar, territorial. A primeira regra concreta dos agenciamentos é descobrir a territorialidade que envolve, pois sempre há uma: dentro de uma lata de lixo ou sobre o banco, os personagens de Beckett criam para si um território. Descobrir os agenciamentos territoriais de alguém, homem ou animal: "minha casa" (Deleuze; Guattari, 1997, p. 218).

Como não pretendemos, neste texto, esgotar a discussão sobre os termos "desterritorialização" e "reterritorialização", advindos das mais diferentes ciências, esclareceremos apenas os tópicos que podem fundamentar nossa compreensão da saga marcada pela mobilidade identitária e pela migração, no sentido mais amplo: pessoas, espaços, valores e identidades migram o tempo todo. Para tanto, pautamo-nos principalmente pela visão da crítica literária, mais precisamente aquela oriunda dos Estudos Culturais, nos conceitos de Néstor García Canclini, que, ao retomar a questão do nômade, considera também que ao movimento de desterritorialização sucede o de relocalização ou reterritorialização e pode enfraquecer ligações de pertencimento:

O pensamento pós-moderno redefine os sujeitos como nômades. Baseado nas experiências de migrantes, artistas e exilados, e sem levar muito em conta as estruturas econômicas e socioculturais, os fluxos de mensagens e bens que possibilitam a experiência nômade, esses autores exaltam a desterritorialização e veem o enfraquecimento dos laços de pertencimento nacionais ou locais como uma libertação (Deleuze, Guattari, Lyotard). Em vez das estruturas duráveis de sentimentos, relocalização tática de experiências e condutas (CANCLINI, 2007, p. 202). 


\section{Mobilidade e constituição dos sujeitos}

No plano formal, o romance, organizado em sete capítulos, apenas numerados e relativamente longos, apresenta um narrador que também protagoniza a história e a constrói sobretudo por sua mobilidade entre personagens e fatos, elaborados a partir de conversas com o avô Hideo e com tio Hanashiro, recurso importante para a constituição e reconhecimento de sua própria identidade. Logo no início do relato, uma espécie de consciência narrativa reconhece o poder e a responsabilidade do tempo no processo de mobilidade e constituição dos sujeitos, configurando, inclusive, o espaço discursivo como metalinguagem:

Homens e mulheres se instauram em algum momento, depois o tempo impõe os extravios. O tempo - sua reta inflexível como o traçado de uma flecha certeira no ar, sua norma inquestionável e singular - vai manchando as imagens, apagando algumas palavras, gravando ruídos no verbo, e logo se duvida do que foi dito, ou se necessita preencher as elipses, realçar os contornos para que se possa ver, ou inventar traços e cores em folhas em branco (NAKASATO, 2011, p. 9).

O processo de des(re)territorialização organiza a macroestrutura narrativa e resume a saga do velho Hideo que, ao longo da vida, não desiste do sonho de retornar ao território de origem, mas não o efetiva, cabendo ao neto, o narrador, a realização desse propósito. Único membro da família a retornar ao Japão, um dekassegui cumprindo o desejo de reterritorialização do avô, o narrador, Noboru, revela a consciência de que cabe a ele promover o reencontro com território:

Não sei o que lhes [aos amigos] dizer. Não os convencerei dizendo que é mais que um trabalho de dekassegui, que trabalhar como operário não é um objetivo, mas um meio, que outro não existe, e que ir ao Japão é quase um retorno, que na primeira oportunidade me desvencilharei dos sapatos, pisarei a areia branca e sentirei um contato antigo, os pés revivendo o toque, moldando-se a formas desenhadas há muitos e muitos anos e ignoradas pelo tempo, que me sentarei num campo de cerejeiras brancas e permanecerei ali por uma, duas horas, que irei aos pés do monte Fuji, olharei o pico coberto de neve e o reconhecerei, que será um reencontro" (NAKASATO, 2011, p.162).

No que se refere à construção do mundo narrado, já no primeiro capítulo, percebemos o jogo promovido pelo olhar do narrador que, do presente, em primeira pessoa - "Sei pouco de Kimie" (NAKASATo, 2011, p. 9) -, vê e relata ações e emoções já vividas por outras personagens, provocando um movimento constante de cruzamento de fronteiras temporais: "Depois, quando o navio chegou ao porto de Santos, vi Kimie se espremendo em meio a homens e mulheres maiores que ela, procurando um espaço na amurada" (NAKASATO, 2011, p. 17). Porém, na progressão do 
relato, o "eu" vai cedendo espaço ao "ele", e as demais personagens assumem identidades próprias: "Depois, ainda deitada, pensou nos filhos. Pensou em cada um, e de repente eles estavam distantes, como se fossem crianças sobre as quais alguém lhe contara" (NAKASATO, 2011, p. 121).

Além do narrador, que realiza o ciclo (re)territorialização, outras personagens cada qual a seu modo - revelam-se peças importantes na realização dessa jornada, notadamente Kimie, a primeira mulher de Hideo, o tio Haruo, a mãe, Sumie, bem como Jintaro, que consegue voltar ao Japão. Embora o narrador não conhecesse Kimie, e nem tivesse qualquer parentesco com ela, é com a beleza de seu desvario que promove a interação dos territórios - a neve do Japão sobre o cafezal no interior de São Paulo - procurando explicar seu próprio desejo de reterritorialização, a volta às origens. A curta e intensa trajetória de Kimie no mundo narrado sintetiza as dificuldades de inserção do imigrante japonês na comunidade paulista, com o desconhecimento total da língua, o primeiro contato com os negros - gente muito diferente -, o trabalho duro no cafezal, o desconforto no contato com a nova terra, especialmente em razão da precariedade da morada a eles destinada:

Ela [Kimie] examinou as cortinas penduradas em arames isolando dois cômodos que ficavam ao lado, uma gravura com árvores e morros esquecida pelos ex-moradores fixada com pregos na parede. Foi ao aposento ao lado, que lhe parecia ser um quarto, mas sentiu falta de um armário para guardar as roupas e de uma cama (NAKASATO, 2011, p. 20).

Mas é também pela experiência de Kimie que percebemos os movimentos iniciais de territorialização no comportamento das personagens, como as primeiras tentativas de contato com o outro, caso dos negros e dos italianos: "E as duas, a japonesa e a negra, tornaram-se amigas" (NAKASATO, 2011, p.27). Embora os considerasse seres inferiores e não permitisse a amizade da mulher com a negra Maria, Hideo se vê impelido a manter contato com ela, para agradecer-lhe os cuidados com a esposa doente:

Então, após o trabalho na lavoura, Hideo colheu muitos tomates e dois repolhos, pegou um frango no quintal, levou-o à casa de Maria. Curvou-se três vezes diante da mulher, estendeu os presentes, agradeceu:

- Kimichan agora está boa (NAKASATO, 2011, p. 29-30).

Se Kimie sonhava com a neve do Japão sobre o cafezal, numa síntese do processo de desterritorialização, Jintaro, agregado à família de Hideo, buscava na literatura a possibilidade de seu retorno ao território. Na madrugada, desesperado com os ruídos do quarto contíguo, as carícias do marido na jovem mulher - por quem estava apaixonado -, escrevia seus haicais sobre imagens das estações do ano no Japão, seu modo de reencontrar-se com a terra distante: 
Então [Jintaro] ia para a cozinha. À noite, de madrugada, era o seu templo privado, lugar de frigir as incertezas, debruçar-se sobre as angústias, inscrever na ausência do passado as sua lembranças. Acendia a lamparina, deixava a chama alta para ver melhor, para não ver fantasmas, e escrevia sobre as quatro estações do ano: a triste vermelhidão do céu que as folhas de momiji copiavam no outono, o manto branco sobre as cerejeiras durante o inverno, o canto do rouxinol saudando a primavera, a sinfonia das cigarras nas noites de verão. Era um modo de sentir o Japão.

Um dia, mostrou um de seus poemas a Kimie:

Vejo no momiji

$\mathrm{O}$ vermelho triste do céu.

Cor de outono (NAKASATO, 2011, p.35-36).

Ao tratar da travessia entre o Japão e o Brasil, empreendida por Hideo, Kimie e Jintaro, o narrador desvela o traumático processo de inserção de estrangeiros em um mundo novo, desconhecido, "com homens estranhos, que podiam ser violentos, que poderiam querer impor normas difíceis ou até impossíveis de serem cumpridas por japoneses" (NAKASATO, 2011, p. 13). Ainda que a recepção aos imigrantes no porto de Santos, feita pelos japoneses que já moravam no Brasil, tenha restaurado algum sentimento de pertencimento no espírito das personagens, o receio do diferente instaura-se no espírito dos assutados viajantes: "Logo as outras caras, criaturas estranhas, e principalmente a visão assustadora dos negros, estivadores carregando enormes cargas, gente jamais imaginada, nunca vista em gravuras de livros" (NAKASATO, 2011, p. 17).

Após o fracasso da primeira tentativa de enraizamento de Hideo, com a morte de Kimie e a partida de Jintaro, apresenta-se-lhe nova possibilidade, vislumbrada pela constituição de outra família: o arrendamento de um sítio, o casamento com Shizue e o nascimento dos filhos. A ligação com o território de origem, ainda que não tivesse mais certeza de que retornaria ao Japão, é mantida, além da preservação dos costumes, pela leitura das cartas que recebe do país distante:

Elas [as cartas] davam elementos para que ojiichan seguisse elaborando a história da família, que permanecera no Japão, garantiam o aperto dos laços que o prendiam àquele país. Através delas sentia a presença dos pais, dos irmão, sobretudo da mãe, que frequentemente lhe aparecia nos sonhos, às vezes com o semblante triste da despedida, outras vezes com o sorriso que sempre lhe iluminava o rosto quando ele e seus irmãos, ainda crianças, retornavam da escola (NAKASATO, 2011, p. 45).

A certeza do rompimento gradual dos laços com a terra de nascimento aprofunda-se no espírito de Hideo com a morte da mãe. A dor experimentada com a leitura da carta revela a consciência de que não haverá o retorno: "Era uma carta de duas folhas com letras borradas de um canto a outro [...], em que sua irmã contava 
que a mãe adoecera repentinamente e morrera pouco mais de uma semana após a primeira crise de dor de cabeça e febre" (NaKASATO, p. 2011, p. 56).

As dificuldades do processo desterritorialização/reterritorialização manifestam-se mais fortemente no seio da família de Hideo, dividida pelos conflitos enfrentados pelo filho Haruo - entre ser brasileiro e ser japonês, as consequentes discussões e os castigos infringidos pelo pai ao menino - e pela atitude de Sumie, a filha que deixa a família para viver com um gaijin, promovendo a fragmentação da identidade das personagens: Hideo, apoiado pelas forças da tradição, luta para manter a integridade nipônica em um espaço inóspito; Haruo e Sumie, por sua vez, travam um embate tenso tanto com a família, que condena e pune suas formas de desenraizamento, quanto com o novo território, que dificulta o processo de pertencimento de ambos. A batalha identitária se dá entre o desejo de se construir como participante de uma sociedade igualitária, que valoriza a alteridade, e o sentimento daqueles que, sentindo-se ameaçados, resistem, valendo-se da intolerância escancarada, que promove o silenciamento do Outro e o soterramento da diversidade (HALL, 2003). A consciência de ser diferente impele Haruo à busca da igualdade e da inserção no novo território.

As tensão do momento histórico em que se movem as personagens Governo Getúlio Vargas e a Segunda Guerra Mundial - é o complicador do processo "desterritorialização/reterritorialização" empreendido pelas criaturas ficcionais, que toma, principalmente, dois rumos. De um lado, Hideo associa-se à Kodosha, primeira manifestação da Shindo Renmei, também chamada Liga do Caminho dos Súditos, que tinha como objetivo "unificar a colônia japonesa no país e manter os laços de fidelidade ao imperador” (NAKASATo, 2011, p. 91), composta por imigrantes que não aceitavam a derrota do Japão e não acreditavam na rendição do imperador - os kachigumis; na outra direção caminham personagens que lutam pela integração na nova terra - os makegumis, ou "corações sujos". Para aliciar seguidores, a Shindo Renmei, organização nacionalista japonesa fundada em Marília, interior de São Paulo, em 1942 (antes da entrada do Brasil na Segunda Guerra Mundial), influenciada por ex-militares nipônicos que vieram para o Brasil, sustentava-se no desejo de reterritorialização de cada japonês, a prometida volta ao Japão, como podemos ler em Corações sujos, de Fernando Morais:

Durante os anos de 1944 e 1945 a Shindo realizou um silencioso porém frenético trabalho de catequese patriótica e de aliciamento de associados. Segundo um relatório feito pela polícia após o final da guerra, "um verdadeiro exército de colonos, verdureiros, tintureiros, vendedores ambulantes e sapateiros" varou o estado de ponta a ponta. Sob os mostruários da Casa Paulista, as malas dos falsos mascates escondiam boletins, panfletos e recortes de jornais e de 
revistas cujo conteúdo poderia ser resumido em uma ideia fixa: o desempenho da pátria na Segunda Guerra Mundial tinha sido excelente, o Japão nunca perdera uma guerra, o imperador continuava vivo etc. etc. Além de notícias falsas, quase sempre - cada agente levava no bolso um panfleto intitulado "De como instalar sucursais", que funcionava como um roteiro de reuniões. Ele continha instruções genéricas, tais como os objetivos da Shindo Renmei, a forma de selecionar os diretores das sucursais, orientação religiosa e política. Ensinavam-se cuidados para que a correspondência não fosse violada pela polícia e até como realizar com êxito o trabalho de sabotagem de "atividades produtivas de interesse militar do inimigo”. Todo sócio deveria ter obrigatoriamente, além de firmes convicções patrióticas, "um passado de procedimento moral sem manchas". Mas era a parte final das preleções que enchia de alegria a alma dos japoneses. O último capítulo das conversas era dedicado à organização do repatriamento: o regresso em massa de todos os japoneses do Brasil não ao łapão, mas à prometida "Grande Ásia Oriental” em que a pátria se transformaria após a vitória sobre os Aliados (MoraIs, 2000, p. 61, grifo nosso).

A atuação da Shindo Renmei não foi pacata; não se resumia a veicular informações e instruções aos compatriotas. Ao contrário, muito violenta, espalhava o terror pela colônia nipônica, nas pequenas cidades do interior de São Paulo, executando aqueles que acreditavam na rendição do Imperador e na derrota do Japão, conforme Morais: "O atrevimento da Shindo Renmei, ao executar três pessoas em menos de 24 horas, na mesma cidade, foi entendido como pela polícia como um desafio" (MorAIs, 200o, p. 115).

O sonho de repatriação, a crença de que o Japão vencera a guerra, a manutenção do mito da divindade do imperador, valores estimulados por panfletos da Shindo Renmei e considerados uma espécie de delírio coletivo por Haruo, levam-no a publicar um artigo no qual desmascara os fundamentos da Shindo Renmei, assumindo sua condição de makegumi. Com o episódio, porém, conhece a força da ameaça na frase pichada no muro de sua casa - "Lave a sua garganta, traidor” - espécie de sentença de morte da organização a quem a confrontasse:

Haruo sabia que o motivo era o artigo que publicara no jornal havia dois dias. A esposa, a quem mostrara o texto antes, insistiu para que não levasse ao editor, disse que era uma temeridade, embora concordasse com o que estava escrito. Ele lembrou o episódio de 11 de setembro do ano anterior, quando cerca de dois mil japoneses tinham descido ao Porto de Santos para aguardar a chegada de uma esquadra da Marinha Imperial Japonesa, que, de acordo com informações recebidas dos kachigumes, repatriaria a todos eles (NAKASATO, 2011, p. 132).

O processo de convencimento dos kachegumes não se resumia aos panfletos e à violência física, na maioria das vezes mortal, da Shindo Renmei. Havia também uma espécie de guia ideológico da organização, a revista Hiraqui, ou Fulgor, em português, 
cujos textos alicerçavam os devaneios da população nipônica no Brasil, segundo Fernando Morais:

Ler um número qualquer de Hiraqui era tomar conhecimento do grau de perturbação mental em que viviam os ideólogos da seita. Um interminável ensaio publicado em uma edição de 1946 dedicava-se a refletir se era falsa ou verdadeira a notícia de que "os Estados Unidos realizaram no ano passado, na ilha Biquíni, uma experiência com a bomba atômica, [...] a qual nada mais fez que provocar o naufrágio de uns dois navios de pequena tonelagem". Isso foi escrito e publicado mais de seis meses depois de Hiroshima e Nagasaki terem sido pulverizadas por bombas atômicas, matando 100 mil japoneses. Segundo o articulista, a fracassada experiência americana com a energia nuclear "só serviu para provocar uma boa gargalhada pelo mundo todo". Outra ideia fixa dos redatores de Hiraqui era a "unificação monetária do mundo". O autor concluía que a utilização de uma única moeda em todo o planeta "seria uma revolução para o mundo financeiro, não restando a menor dúvida de que estão em curso as conferências para a concretização desse ideal (MoRAIs, 200o, p. 107).

Entretanto, se havia violência por parte dos súditos fieis ao Imperador, os kachegumis, também houve, a partir da entrada do Brasil na Segunda Guerra, uma forte perseguição aos japoneses, que passaram a ser vistos como inimigos da pátria. O então presidente Getúlio Vargas decretou severas punições aos imigrantes que desobedecessem a proibições como escrever no idioma japonês, cantar hinos ou fazer uso da língua em concentrações públicas, viajar sem salvo-conduto, entre tantas outras ordens cerceadoras da liberdade. A exacerbação do ufanismo e dos ideais xenófobos, consolidados com a ascensão de Vargas ao poder, responsabilizou-se pelo sentimento de rejeição em relação aos japoneses e Hideo, um dos heróis da resistência japonesa no mundo narrado, conhece a força do preconceito em sua trajetória "desterritorializadora". Preso, considera a dificuldade da situação da população nipônica no Brasil, com as arbitrariedades praticadas pelo governo, que visavam não só ao enfraquecimento da identidade nihonjin, como apontavam para a sobrevivência do preconceito contra negros e amarelos, veiculado de forma pretensamente científica no texto de Arthur Gobineau, o Ensaio sobre a desigualdade das raças humanas, de 1855-1858, ao afirmar a superioridade da raça ariana:

Havia a guerra, e as pessoas pareciam estar enlouquecendo. Sempre [Hideo] entendera a cadeia como punição para quem matava ou roubava, era o que não se podia fazer no Brasil ou no Japão, em qualquer lugar, e então ao polícia começava a prender nihonjin porque nihonjin era nihonjin (NAKASATO, 2011, p, 88).

Ojiichan disse que o Brasil não era um país de pessoas livres, que o governo perseguia mais os japoneses que os italianos e alemães porque eram diferentes, não se confundiam com os outros em meio à multidão. Não poder ter em casa livros escritos em língua japonesa, que disparate! Que livros, afinal, deveria ter 
um japonês em seus armários? Não poder falar em japonês, ora essa! Era sua língua, que usava para dizer bom dia e boa tarde, para comentar os resultados do último jogo de beisebol, para perguntar o preço de um repolho ao dono da quitanda, para ficar longas horas conversando com Hikarisan sobre a metereologia, sobre como São Paulo estava crescendo, sobre a infância no Japão, sobre a guerra (NAKASATO, 2011, p. 90).

A referência à obra de Gobineau, amigo do imperador Pedro II, que esteve no Brasil como embaixador da França na corte, fundamenta a existência do mito a respeito do "perigo amarelo", a aversão de brasileiros aos nipônicos, a hostilidade em relação a esses imigrantes, divulgada por intelectuais, articulistas e políticos, como José de Oliveira que

dizia a quem quisesse ouvir que os amarelos, como os negros, eram um estorvo, e lembrava a campanha do deputado Fidélis Reis, que já em 1923 apresentara ao Congresso Nacional proposta para reduzir a entrada de japoneses no Brasil, justificando a sua proposta na ideia que tinha de que a raça ariana era superior e responsável pelos progressos da civilização, como ensinava o francês Arthur Gobineau na obra Ensaio sobre a desigualdade das raças humanas (NAKASATO, 2011, p. 86).

No que diz respeito à Sumie, sua atuação também é de rebeldia, como Haruo. Para os japoneses, o casamento com iguais garantiria, de certa maneira, a reterritorialização, uma vez que a cultura, as crenças e a raça seriam preservadas. Um forma de reconstituir o território no campo dos valores sociais, culturais e familiares, como fez a mãe Shizue que, ao casar-se com Hideo, assume e procura manter as funções da mulher na família oriental. Quando, em dúvida sobre seu destino, Sumie pergunta à mãe se era feliz, ela responde que sim e resenha sua vida, ressaltando que a felicidade também poderia ser a superação das dificuldades que vivera:

De que adiantava pensar que poderia ter sido diferente? A vida lhe reservara um homem bom, exigente e duro, de quem aprendera a gostar e a quem aprendera a respeitar. Assistiu à sua batalha diária, primeiro na Fazenda Ouro Verde, depois no sítio que arrendara com seu pai, empunhando a enxada aos sábados e domingos, só guardando o dia do Imperador, por fim na pequena loja no bairro da Liberdade. Viu o marido trabalhar sem descansar para retornar ao Japão, depois viu seu sonho se acabando aos poucos. Ele nunca lhe disse que desistira, mas não era preciso que lhe dissesse (NAKASATO, 2011, p. 110)

Após o diálogo com a mãe, Sumie aceita a situação, casa-se com um nihonjin, Ossamu, tem filhos, mas rompe com a tradição ao deixar a família para viver com um brasileiro, abrindo-se para o outro e para a diferença. Reterritorializa-se, por outros caminhos, com atitudes e ações impensáveis para uma mulher japonesa. Podemos afirmar que ocorre com Sumie o que Zilá Bernd, discutindo o pensamento de Michel Maffesoli, em Du nomadisme (1997), denomina enraizamento identitário, pois: 
A necessária abertura para o outro e para a relação dá espaço a um oxímoro: enraizamento identitário, que remete a uma construção identitária baseada afirmação da pertença a um lugar, mas concebendo, ao mesmo tempo, a necessária abertura para o outro, para a diversidade e para a relação (BERND, 2010, p.305).

Com a atuação de Sumie no mundo narrado, percebemos também todo o movimento descrito por Deleuze e Guattari, em Mille plateaux: capitalisme et schizophrénie (1980). Ao deixar o marido e os filhos, Sumie desvia-se de seu território de origem, a cultura nipônica, desterritorializando-se, portanto. Ao mesmo tempo, observamos que, ao deixar o território e os valores resguardados pela tradição familiar, a jovem senhora cumpre um processo diferenciado de reterritorialização, encontrando, ao lado do marido Fernando, um gaijin, seu lugar na nova sociedade brasileira em formação:

Na noite da partida, Sumie repetiu tudo: sem acender as luzes, pois as luzes incomodariam Ossamu, que se incomodava mais com luzes que com barulho, retirou do guarda-roupa o mínimo necessário, colocou as roupas numa mala. Depois foi à cozinha, escreveu ao marido uma carta de poucas linhas: que era um homem e um marido exemplar, que os filhos eram bons, mas que isso não era suficiente para fazê-la feliz, e por isso os deixaria para viver com o homem que amava, o homem com quem deveria ter partido dez anos antes, um homem que o pai não aceitaria, pois era gaijin (NAKASATO, 2011, p. 120-121).

Haruo, por sua vez, cumpre também todos os protocolos do enraizamento identitário, na medida em que luta contra a família e contra a organização Shindo Renmei, tornando-se um makegumi, mas não consegue vencer a brutalidade daqueles que não aceitam sua visão divergente em relação aos resultados da Segunda Guerra Mundial, manifesta em artigo sobre a derrota do Japão. Despreza, inclusive, a última chance de retorno ao território quando não comete o "haraquiri", a prática do suicídio como forma de recuperar a honra, seu último ato no processo de desreterritorialização:

Haruo percebeu que era inútil: os tokkotais haviam sido bem instruídos, eram ignorantes e determinados. Ele olhou o pai, que estava impassível em um canto da sala, caminhou lentamente em direção ao homem que segurava a bandeira e a adaga, levantou as mãos para pegá-las, mas, em vez de fazê-lo, empurrou com força e correu para a porta. Não cometeria haraquiri, não tinha feito nada de que se arrependesse ou de que se envergonhasse, não era um criminosos. Morreu ainda na varanda, atingido por dois tiros disparados por dois tokkotais que estavam à espreita (NAKASATO, 2011, p. 158).

A história de cada uma das criaturas do mundo narrado revela como, ao sofrerem o processo de desterritorialização, empreendem, ao mesmo tempo, a reterritorialização, promovendo a reconstrução de suas identidades. Mesmo Hideo, que desiste de retornar ao Japão, tenta de todas as formas viver no Brasil como se estivesse na sua 
terra natal, lutando, inclusive, para que os filhos mantivessem vivas as tradições japonesas: "Hideo era uma ponte firme que levava seus filhos ao Japão. Ponte de concreto, construída ao longo dos anos, com pilares grossos fincados na terra, sobre a água turva. Por que, então Haruo não a atravessava?” (NAKASATo, 2011, p. 93).

\section{Espaços de enraizamento: a casa e a escola}

No estudo do processo de territorialização/desterritorialização por que passam as personagens, ressaltamos a importância do ambiente, notadamente, de dois espaços: a casa e a escola. Gaston Bachelard, em A poética do espaço, a partir do estudo fenomenológico dos valores da intimidade, nos apresenta a casa como "uma das maiores (forças) da integração para os pensamentos, as lembranças e os sonhos do homem" (BACHELARD, 1988, p. 26), e, ao considerar que "é preciso dizer como habitamos o nosso espaço vital de acordo com todas as dialéticas da vida, como nos enraizamos, dia a dia, num canto do mundo" (BACHelARD, 1988, p. 24), complementa: "Porque a casa é o nosso canto do mundo. Ela é, como se diz amiúde, o nosso primitivo universo. É um verdadeiro cosmos" (BAChelard, 1988, p. 24). Essas concepções, oriundas da topoanálise - "o estudo psicológico sistemático dos locais de nossa vida íntima” (BACHELARD, 1988, p. 29) - sustentam a noção de que a casa, em Nihonjin, como elemento fundamental na organização do território simbólico, desempenha função imprescindível para a inserção do imigrante na comunidade do interior paulista. As mulheres, Kimie e Shizue, principalmente, após o susto inicial com as moradas brasileiras nas fazendas de café - piso de terra batida, divisórias precárias entre os cômodos, sem cadeiras, armários e camas -, procuravam adaptar, cada qual a seu modo, esses espaços aos costumes e às necessidades da família japonesa:

Depois vi Kimie cuidando da casa, e a casa não era muito diferente daquela que encontraram no primeiro dia, embora houvesse na entrada dois canteiros de margaridas que ela plantara, um canteiro de cada lado, e estavam floridos, e as pétalas alvas contrastavam com as paredes sujas. Na sala não havia mesa e cadeiras como a casa de Maria, por isso sobrava um grande vazio no meio. Havia um estrado de madeira encostado à parede com sacos de mantimentos, enxadas e rastelos encostados num canto, chapéus e lenços pendurados em pregos, cabaços amarrados em barbantes, também pendurados em pregos, enormes buchas espalhadas pelo chão (NAKASATO, 2011, p. 30-31).

Dois cômodos são importantes na casa que Kimie e Hideo dividem com Jintaro, mas é a cozinha, cuja janela constitui um elo definitivo com o território de origem, pois dali Kimie deseja ver ardentemente cair a neve, como no Japão, e consegue, durante os três anos que viveu na casa, ver a neve sobre o cafezal. E foi justamente essa visão que a levou de volta ao Japão: 
Uma noite, e era a noite mais fria do ano, Kimie não conseguiu dormir. Estava doente. Tomara os chás de Maria, ficara quieta sob as suas mãos enquanto ela rezava aquelas rezas que não entendia, mas não melhorara. De madrugada aumentou a febre. Quis ver a neve. Hideo roncava ao seu lado. Levantou-se, caminhou até a porta da sala e a abriu. A neve cobria a terra. Saiu, correu até o cafezal, correu entre os pés de café, sentindo a neve cair sobre sua cabeça, sobre seus ombros. Correu durante muito tempo, estrela do espetáculo, abrindo os braços, ela, que sempre preferia ficar na janela. Finalmente, quando se cansou, sentou-se na terra fria. A morte chegou lentamente. Há quanto tempo morria? Tranquila, congelada pela neve, congelada pelo sol (NAKASATO, 2011, p. 43).

O pensamento de Bachelard - "todo espaço realmente habitado traz a essência da noção de casa", [pois] "o ser abrigado sensibiliza os limites do seu abrigo. Vive a casa em sua realidade e em sua virtualidade, através dos pensamentos e dos sonhos" (BACHELARD, 1988, p. 25) - permite que compreendamos a razão pela qual a casa no novo mundo, muito desconfortável na chegada dos imigrantes, vai aos poucos adaptando-se aos hábitos dos novos moradores, com a plantação de legumes em uma horta e a construção do "ofurô":

haviam construído um ofurô fora de casa, junto com os Kawahara, seus vizinhos, aproveitando a habilidade de Jintaro, que trabalhava como carpinteiro no Japão; e todos os dias, dias frios e dias quentes, preparavam o banho, e todos de sua família e da família Kawaharasan se banhavam, e às vezes ainda vinham outros vizinhos (NAKASATO, 2011, p. 26).

Ainda na casa, mais que o quarto, é a cozinha o ambiente de manutenção e reprodução dos valores da família japonesa. Nesse espaço, percebemos tanto a submissão das mulheres orientais aos homens, a força do mundo masculino mesmo em um local predominantemente feminino, como o desejo de transformação desse estado de coisas, a partir da contaminação cultural. Quando a família reunia-se à mesa de refeições na cozinha, Hideo e os filhos, sentados, eram servidos pelas mulheres, que permaneciam em pé, à espera que terminassem para que pudessem alimentar-se. Haruo, porém, não aceitava a situação:

A esposa, que também era mãe, e as filhas, que também eram irmãs, aguardavam de pé ao redor da mesa, enchiam o prato que ficava vazio, levavam ao fogão a tigela e a traziam de volta com o missoshiro fumegante. Haruo reclamava, não se cansava de reclamar: que se sentassem também as mulheres à mesa, que era um absurdo aquele costume. Quando se casasse se sentariam à mesa a esposa e o marido, um em frente ao outro, porque não era o homem melhor que a mulher para ser o primeiro, e também porque assim poderiam compartilhar juntos a mesma refeição (NAKASATO, 2011, p. 93). 
Outro espaço importante no processo de desterritorialização/reterritorialização no mundo narrado é a escola, também fundamental na organização do território simbólico. É justamente nesse ambiente que a personagem Haruo, terceiro filho de Hideo com sua segunda mulher, Shizue, reconhece-se dividido, desde criança, entre ser nihonjin ou ser brasileiro. Em casa, o pai exige postura e apego às tradições japonesas - "nihonjin precisa se manter sempre junto de nihonjin [...]. - No meio de gaijin, um nihonjin sozinho é fraco, é uma vara fácil de ser quebrada" (NakAsato, 2011, p. 61) -; na escola, a professora afirma que ele é brasileiro: "Você nasceu aqui, no Brasil, portanto, você é brasileiro. E você deve se sentir orgulhoso por ser brasileiro, afinal, por algum motivo, seus pais escolheram o Brasil para viver" (NAKASATo, 2011, p. 64). Depois de muito perguntar ao pai - e sofrer as punições por não concordar com ele - o menino decide que, de coração, é brasileiro, apesar do formato do rosto, dos olhos puxados e da cor amarelada da pele:

- Seu nome é Haruo [disse o pai] - prosseguiu. Se você fosse brasileiro, se chamaria João, Antonio, José...

- Otõchan, a cara e o nome eu não posso mudar, mas isso não importa muito. Sensei do burajiru gakkõ disse que todos somos iguais, filhos de Deus, não importa se os olhos são puxados ou não, se os cabelos são lisos ou enroladinhos, se o menino é preto ou japonês. O que importa é o que otõchan está dizendo: o coração. E eu sinto que o meu coração é brasileiro.

- Insolente!

O tapa atingiu em cheio a face de Haruo. Imediatamente os olhos se encheram de lágrimas.

- Você é quem seu pai quer que você seja. E você é uma nihonjin! (NAKASATO, 2011, p. 67).

Haruo, "entre as velhas paredes de tábuas caiadas da escola rural, com algumas mata-juntas despregadas e outras ainda grudadas por pregos, fincados por negros que tinham erguido essas paredes para os brancos rezarem, pois antes a escola era uma igreja" (NAKASATO, 2011, p. 60), passa por intenso conflito interno, uma vez que as concepções da professora revelam-se em desacordo com as do pai:

quando ela lhe disse que não era japonês, não enxergou mais seus grandes olhos azuis e lembrou que seu pai sempre lhe ensinara que era nihonjin, que nihonjin era diferente de gaijin, que cada nihonjin era representante de um povo de tradição milenar. Então ou seu pai ou a professora estava equivocado, pois, quando dois diziam coisas diferentes, se um estava certo, o outro estava errado, já que não existiam duas verdades diferentes sobre o mesmo tema (NAKASATO, 2011, p. 63). 
Hideo, como toda comunidade nipônica, exige empenho dos filhos no estudo da cultura da terra natal, na escola dominical de japonês. Mas, com frequência, o professor, Ohara sensei, o procura para relatar a falta de interesse de Haruo pelos deveres escolares. Se a escola rural - o burajiru gakkõ -, com a professora loira, bonita e inteligente, possibilita a reterritorialização do menino no mundo dos gaijin, a de japonês o afasta dos costumes e da família:

Ele [Ohara sensei] chegou se desculpando, disse que sabia o quanto ojiichan zelava pela educação dos filhos, que Hanashiro era o filho que todos os pais desejavam ter, que Hitoshi era compenetrado e que já sabia escrever vários kanjis, mas que não podia deixar de denunciar o mau comportamento de Haruo, que se não o fizesse estaria sendo negligente, que conhecia a sua grande responsabilidade e conselheiro da comunidade japonesa. Disse que meu tio [Haruo] conversava durante as aulas e atrapalhava aqueles que queriam estudar, que fazia desenhos estranhos no caderno enquanto os companheiros realizavam as atividades, desenhos de porcos com asas e homens com rabos e chifres, que mal sabia todos os hiraganas (NAKASATO, 2011, p. 74).

Outro espaço escolar também assume importância no esforço de Hideo para manter pés, coração e mente firmes na terra natal. Ao mudar-se para São Paulo com a família, ele passara a ensinar às crianças o espírito japonês, difundido pela bela e intrincada escrita proibida no período da Segunda Guerra Mundial pelo governo brasileiro, que fechara as escolas japonesas (nihongakkõ) - atividade que o levou à prisão:

Era isso que ensinava naquela noite aos vinte e poucos alunos amontoados num velho galpão de madeira. Meninos e meninas reunidos ao redor de mesas improvisadas com tábuas e cavaletes, sentados em longos bancos, com o cadernos repletos de hiraganas, katakanas e ideogramas. Hideo propusera-se a ser professor voluntário porque aquelas crianças, impedidas pelo governo de ir ao nihongakkõ, não poderiam crescer como se fossem gaijins (NAKASATO, 2011, p. 96).

Por fim, sem esgotar absolutamente o assunto, podemos afirmar que a narrativa explora o conflito inerente ao homem que, em sua eterna mobilidade identitária, busca entender o processo pelo qual se coloca no mundo. De um lado, seres que, mesmo desterritorializados, mantêm-se fiéis aos valores culturais do Japão, ao passado, como forma de reterritorialização; de outro lado, aqueles, cientes da passagem do tempo e da consequente transformação de ideias, buscam integrar-se na nova realidade, reterritorializando-se por outras vias e formas.

Não se trata, porém, de simples volta "ao território original", como advertem Deleuze e Guattari (198o, p. 635), uma vez que aquele que retorna não se relaciona com o território do mesmo modo que aquele que o deixou. Nesse caso, a personagem a ser reterritorializada também não é a mesma que se desterritorializou, pois será o neto a cumprir o processo de reterritorialização, buscando sua identidade 
"antiga" no território impresso em suas memórias. O sentido é proposto, então, pelo jogo entre identidade e alteridade, considerando-se que a concepção de identidade completa-se com a cooperação de seu duplo - alteridade - significado que se fundamenta no pressuposto de que em sociedade, interagimos e somos interdependentes de outros indivíduos. Sob tal foco, apenas mediante o contato com o outro, o "eu individual" pode existir. Essa existência está, portanto, determinada pela visão do outro, pela diferença, complementada pelo olhar do próprio indivíduo. Laplantine (200o), em suas considerações sobre o conceito, observa que a elaboração da experiência da alteridade permite que o indivíduo reconheça que, mesmo seus mais insignificantes traços comportamentais, nada têm de natural e que seu "eu individual" torna-se pleno a partir do conhecimento do outro. O narrador de Nihonjin reconhece a existência de um outro na composição de sua identidade:

Disse-lhe que o ato era ida, mas tinha para mim um sentido de retorno, que às vezes, sem hora certa, nas produtivas situações antes do sono, a mulher adormecida ao lado, diante do semáforo vermelho, alheio à pressa e ao desassossego dos outros, nas caminhadas vespertinas no parque, as imagens do Japão distante não eram hipóteses, sensações inéditas, mas lembranças, pedaços de uma sinuosa estrada secular, em cujas margens eu reconhecia as pedras e os arbustos. Que ouvia sempre Pinkara Kyõdai e Misora Hibari, e as canções localizavam em mim um homem antigo, adormecido em outras situações, que despertava para se sentir curiosamente feliz, mesmo quando as lágrimas vinham. Era esse homem que eu ia procurar no Japão (NAKASATO, 2011, p.173, grifo nosso).

\section{Referências}

Almeida, Marco Rodrigo. Vencedor do Jabuti diz que prêmio causou desconforto. Folha de S. Paulo, São Paulo, 27 out. 2012. On-line. Disponível em: $<$ http://www1.folha.uol.com.br/fsp/ilustrada/74281vencedor-do-jabuti-diz-que-premio-causoudesconforto.shtml>. Acesso em: 10 mar. 2013.

Bachelard, Gaston. A poética do espaço. Tradução de Antonio de Padua Danesi. São Paulo: Martins Fontes, 1988.

BERnd, Zilá. Nomadismo. In: Bernd, Zilá (Org.). Dicionário das mobilidades culturais: percursos americanos. Porto Alegre: Literalis, 2010, p. 301-315.

Canclini, N. G. Diferentes, desiguais e desconectados. Rio de Janeiro: Editora da UfRJ, 2007.

Castello, José. Resenha de 'Nihonjin', de Oscar Nakasato. O Globo, Rio de Janeiro, 30 nov. 2012. On-line. Disponível em: <http://blogs.oglobo.globo.com/prosa/post/resenha-de-nihonjinde-oscar-nakasato-477 057.html>. Acesso em: 10 mar. 2013.

Cozer, Raquel. O que podemos aprender com o jurado C. Folha de S. Paulo, São Paulo, 19 out. 2012. On-line. Disponível em: <http://abibliotecaderaquel.blogfolha.uol.com.br/2012/10/19/oque-podemos-aprender-com-o-jurado-c/>. Acesso em: 10 mar. 2013. 
Deleuze, Gilles; Guattari, Félix. Mille plateaux: capitalisme et schizophrénie 2. Paris: Minuit, 1980.

Deleuze, Gilles; Guattari, Félix. Qu'est-ce que la philosophie? Paris: Minuit, 1991.

Hall, Stuart. A identidade cultural na pós-modernidade. Tradução de Tomaz Tadeu da Silva e Guaracira Lopes Louro. 7. ed. Rio de Janeiro: DPひA, 2003.

IAnni, Octavio. A desterritorialização. In: IAnni, Octavio. A sociedade global. Rio de Janeiro: Civilização Brasileira, 1995, p. 89-105.

Laplantine, François. Aprender antropologia. Tradução de Marie-Agnes Chauvel. São Paulo: Brasiliense, 2000.

Morais, Fernando. Corações sujos. São Paulo: Companhia das Letras, 2000.

NAKasAto, Oscar. Nihonjin. São Paulo: Benvirá, 2011.

Recebido em 8 de novembro de 2016.

Aprovado em 10 de fevereiro de 2017.

\section{Resumo/Abstract/Resumen}

\section{Mobilidade identitária em Nihonjin, de Oscar Nakasato}

Alice Áurea Penteado Martha

Neste artigo, a partir de conceitos como "desterritorialização" e "reterritorialização", termos atribuídos a Gilles Deleuze e Félix Guattari (1992), analisamos o movimento de "des(re)territorialização", entendido como mobilidade na literatura, na obra Nihonjin (Benvirá, 2011), do escritor paranaense de Oscar Nakasato, Prêmio Jabuti 2012. Com a leitura do romance, observamos, no plano formal, as fronteiras por onde se movem o narrador e suas criaturas ficcionais, ressaltando modos de construção do mundo narrado, especialmente, ambientação e sistema linguístico; no plano temático, consideramos a inserção das personagens em novos territórios, engendrados pelo movimento da ação narrativa.

Palavras-chave: Nihonjin, Oscar Nakasato, desterritorialização, reterritorialização, mobilidade identitária.

\section{Identity mobility in Oscar Nakasato's Nihonjin}

Alice Áurea Penteado Martha

This paper, which deals with the concepts of "de-territorialization" and "re-territorialization", attributed to Gilles Deleuze and Félix Guattari (1992), analyzes the movement towards "de(re)territorialization", denoting mobility in literature, in the novel Nihonjin (Benvirá, 2011) by Oscar Nakasato, Brazilian writer from Paranás State, Brazil, who won the 2012 Jabuti Prize. In formal terms, the novel shows the frontier where the narrator and the fictional agents displace themselves, with special emphasis on the 
construction of the narrated world, mainly the milieu and the linguistic system. On the thematic plane, the insertion of the characters into new territories, produced by the movement of the narrative action, is investigated.

Keywords: Nihonjin, Oscar Nakasato, de-territorialization, re-territorialization, identity mobility.

\section{Movilidad de la identidad en Nihonjin, de Oscar Nakasato}

Alice Áurea Penteado Martha

En este artículo, a partir de conceptos como "desterritorialización" y "reterritorialización" expresiones atribuidas a Gilles Deleuze y Félix Guattari (1992), analizamos el movimiento de "des(re)territorialización", entendida como movilidad en la literatura, en la obra Nihonjin (BENviRÁ, 2011), del escritor paranaense Oscar Nakasato, vencedor del Premio Jabuti 2012. En la lectura de la novela, observamos, en el plano formal, las fronteras en las cuales se mueven el narrador y sus criaturas de ficción, acentuando los modos de construcción del mundo narrado, especialmente, la ambientación y el sistema lingüístico; en el plano temático, consideramos la inclusión de los personajes en nuevos territorios, engendrados por el movimiento de la acción narrativa.

Palabras clave: Nihonjin, Oscar Nakasato, desterritorialización, reterritorialización, movilidad de la identidad. 